This article was downloaded by: [University of Sydney]

On: 13 March 2015, At: 06:23

Publisher: Routledge

Informa Ltd Registered in England and Wales Registered Number: 1072954

Registered office: Mortimer House, 37-41 Mortimer Street, London W1T

3J H, UK

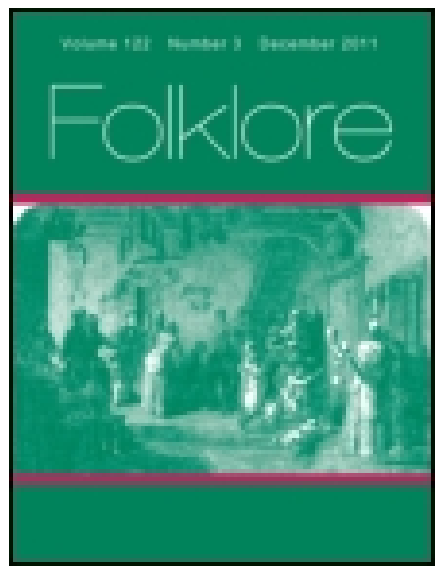

\title{
Folklore
}

Publication details, including instructions for authors and subscription information:

http:// www. tandfonline.com/loi/ rfol20

\section{Berber Corn-Festival}

J. H. Round

Published online: 14 Feb 2012.

To cite this article: J. H. Round (1896) Berber Corn-Festival, Folklore, 7:3, 306-307, DOI: $10.1080 / 0015587 X .1896 .9720373$

To link to this article: http:// dx. doi. org/ 10.1080/0015587X.1896.9720373

\section{PLEASE SCROLL DOWN FOR ARTICLE}

Taylor \& Francis makes every effort to ensure the accuracy of all the information (the "Content") contained in the publications on our platform. However, Taylor \& Francis, our agents, and our licensors make no representations or warranties whatsoever as to the accuracy, completeness, or suitability for any purpose of the Content. Any opinions and views expressed in this publication are the opinions and views of the authors, and are not the views of or endorsed by Taylor \& Francis. The accuracy of the Content should not be relied upon and should be independently verified with primary sources of information. Taylor and Francis shall not be liable for any losses, actions, claims, proceedings, demands, costs, expenses, damages, and other liabilities whatsoever or howsoever caused arising directly or indirectly in connection with, in relation to or arising out of the use of the Content.

This article may be used for research, teaching, and private study purposes. Any substantial or systematic reproduction, redistribution, reselling, loan, sub-licensing, systematic supply, or distribution in any form to anyone is 
expressly forbidden. Terms $\&$ Conditions of access and use can be found at http://www.tandfonline.com/page/terms-and-conditions 
opened for the operation. Dr. Mead contributed an interesting paper to the Procecdings of the Somersetshire Archaological and Natural History Society for 1892 (pp. $3^{62}$ seqq.) on the superstition, from which I add the following account of the manner in which the rite is performed in the neighbourhood of Bishop's Lydeard :

"First of all a ground ash-tree must be selected-a maiden ash $-\mathbf{a}$ tree which had grown up without ever having been topped or cut. The tree must be sufficiently large to allow the child to be passed through a longitudinal fissure, formed by partly clearing the stem and holding open the sides of the tree by suitably-applied wedges. $\Lambda$ ligature applied to the upper end of the split would prevent its going too far. The ceremony must take place in the early morning, at the time of the rising of the sun, the prepara. tions necessary being made in the dawn. The child must be first stripped naked and passed from east to west through the fissure, 'between the barks,' as a commonly used expression has it. ' $\Lambda$ virgin must introduce the child, and a boy take him out on the other side. He should be passed feet first. I need not add that cure was assured to the patient, but under certain conditions following. Immediately after the ceremony the wedges were to be removed from the tree, when the natural elasticity of the ash would cause the sides to spring together. Further accurate adjustments must be made by the aid of bark bands and a plastcring of mud or clay on the exterior. Then, if the tree grew together and flourished, as it usually did, only having been split longitudinally, cure would follow; if not, the case would remain unaltered. No prayers or incantations were indicated, and, as far as the mystery was imparted to them, any person might act as director of the ceremony."

May I venture finally to refer to The Legend of Perseus, vol. ii. p. 146 , where further references will be found and a short discussion of the meaning of the rite?

E. Sidney Hartiand.

\section{Berder Corn-Festival.}

As Mr. Gomme informs me that he believes the following interesting extract from the late Sir John Drummond Hay's 
PI.ATK III.

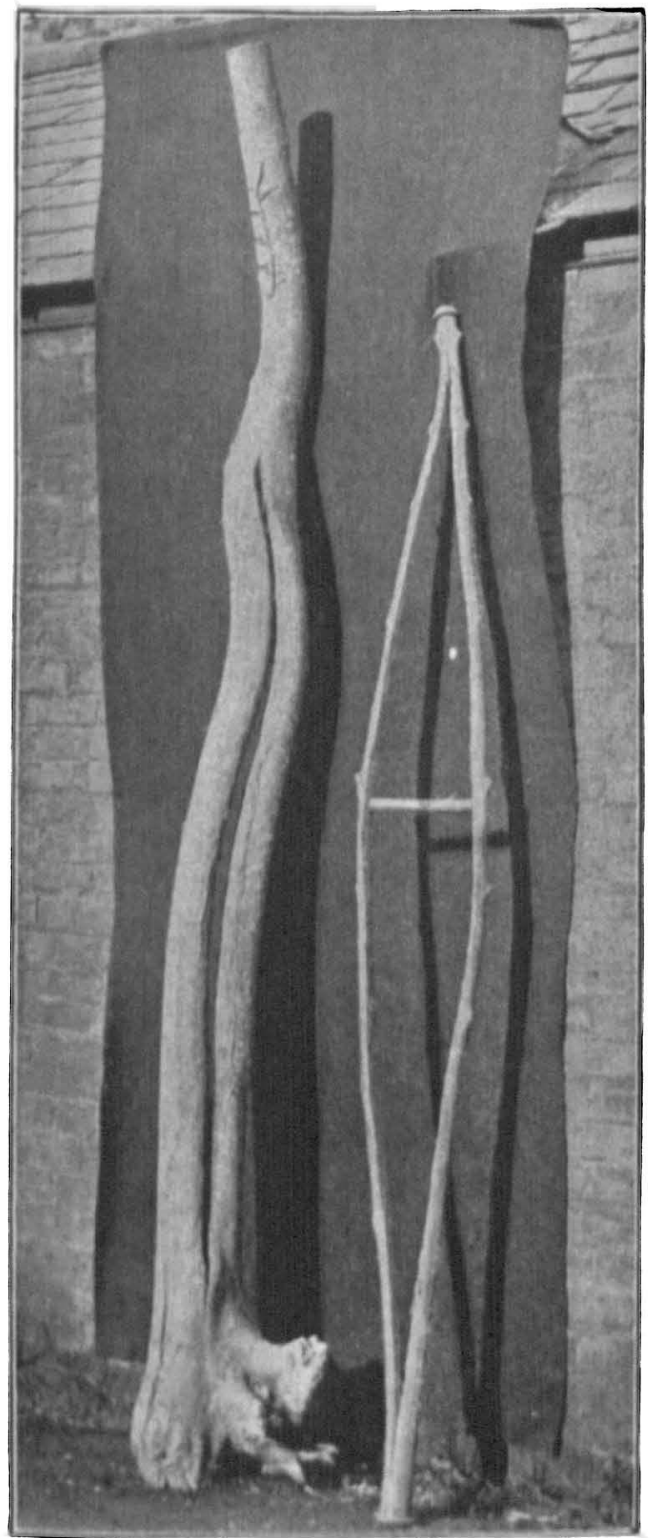

SPLIT ASH-SAPLING AND MODEL IN TAUNTON MUSEUM. 
IVestern Barbary: its IVild Tribes and Savage Animals, chap. ii. p. 9 (Murray, 18.44) not to have been noted for folklore purposes, $I$ beg to subjoin it :

"There is a curious custom which scems to be a relic of their pagan masters, who made this and the adjoining regions of North Africa the main granary of their latin empire. When the young com has sprung up, which it docs about the middle of February, the women of the villages make up the figure of a female, the size of a very large doll, which they dress in the gaudicst fashion they can contrive, covering it with ornaments to which all in the village contribute something; and they give it a tall peaked henddress. This image they carry in procession round their ficlds, screaming and singing a peculiar ditty. The doll is borne by the foremost woman, who must yicld it to any one who is quick cnough to take the lead of her, which is the cause of much racing and squabbling. The men also have a similar custom, which they perform on horseback. They call the image Mata.

These ceremonics are said by the people to bring good luck. Their efficacy ought to be great, for you frequently see crowds of men engaged in their performances running and galloping recklessly oicr the joung crops of wheat and barley.

"Such customs are directly opposed to the faith of Islam, and I never met with a Mfoor who could in any way enlighten me as to their origin.

"The Berber tribes, the most ancient race now remaining in these regions, to which they give the name, are the only ones which retain this antique usage, and it is viewed by the Arabs and dwellers in the town as a remnant of idolatry."

J. II. Rouxd.

\section{Devil Dances in Cerlon.}

The dance here described occurred at Colombo on the night of January 17 th, 1896 . The object was to curc a woman ill with ferer by exorcising the demon whose presence in her body was believed to be the causc.1 The dance took place at the end of a

I There are different demons, I believe, for different maladics, as among Joman Catholies there are diferent snints for them. 